\title{
ATVEJO VADYBOS TAIKYMAS KLAIPE்DOS UNIVERSITETINĖJE LIGONINĖJE KURIANT PERSONALIZUOTĄ ONKOLOGINIŲ LIGONIŲ SVEIKATOS PRIEŽIŪRĄ
}

\author{
Samanta Savickaitè ${ }^{1}$, Alvydas Česas ${ }^{2}$ \\ ${ }^{1}$ Klaipeddos universiteto Socialiniu ir humanitariniu mokslu fakultetas, \\ ${ }^{2}$ Klaipeddos universitetinès ligoninès Onkologijos chemoterapijos klinika
}

Raktažodžiai: atvejo vadyba, personalizuota (i asmeni orientuota) pagalba, kompleksinis gydymas, integrali sveikatos priežiūra, holistinis požiūris

\begin{abstract}
Santrauka
Onkologinių ligų sveikatos priežiūra reikalauja individualios vadybinès prieigos dèl šios ligos sudètingumo ir didelių gydymo kaštų. Siekiant efektyviai ir veiksmingai suvaldyti navikinių ligų keliamus iššūkius, personalizuotos (i asmeni orientuotos) pagalbos taikymas šiandien laikomas palankiausiai vertinama alternatyva, aukščiausios paslaugų kokybès ir pacientų pasitenkinimo paslaugomis garantas. Pabrèžtina, kad personalizuota onkologinių ligonių sveikatos priežiūra, paremta holistiniu požiūriu, skatina iggyvendinti rimtus pokyčius organizaciniu lygmeniu. Kaip pasekmè, rutininejje gydymo ịstaigų veiklos praktikoje vis dažniau pradedama taikyti atvejo vadyba. Tyrimo tikslas: mokslinès literatūros pagrindu ịvertinti atvejo vadybos taikymo ypatumus klinikineje praktikoje bei pristatyti Klaipėdos universitetinejje ligoninejje taikomą atvejo vadybos modelį.
\end{abstract}

\section{İvadas}

Onkologinès ligos pasaulio sveikatos statistikoje, neišskiriant ir Lietuvos, pagal mirtingumo ir sergamumo rodiklius užima pirmaujančias pozicijas $[1,2]$ ir ši tendencija nuolat stiprëja. Akcentuotina, nors vėžys dẻl ypač didelių ir sunkiai suvaldomų gydymo kaštų laikomas kaip vienas didžiausių iššūkių šiuolaikinėms sveikatos priežiūros sistemoms ekonomine prasme [3,4], gausa mokslinių tyrimų pabrěžia ir šios ligos psichosocialinị aspektą, kuomet dèl ligos sukeliamo streso ir distreso sergančiujų gyvenimo kokybė gali reikšmingai suprastetti ir neigiamai paveikti gydymo procesus ir rezultatus $[5,6]$.

Pastarujų metų moksliniai tyrimai ir klinikinè praktika irodo, kad norint efektyviai ir veiksmingai įveikti onkologinio ligonio fiziologinių bei psichosocialinių poreikių keliamas problemas gydymo proceso sėkmei, svarbu taikyti individualizuotą paslaugų valdymo prieigą. Pastebėtina, kad pagalbos integruotumas ir kompleksiškumas šiuolaikinejje sveikatos priežiūroje traktuojamas kaip aukščiausios paslaugų kokybès ir pacientų pasitenkinimo paslaugomis garantas. Ši nuostata pažymima ir $2017 \mathrm{~m}$. Europos vėžio kontrolès kokybès gerinimo direktyvoje, kurioje nurodoma, kad onkologiniai ligoniai turi būti gydomi vadovaujantis personalizuotu tarpdisciplininiu metodu [7]. Tuo tikslu rutininèje gydymo įstaigų veiklos praktikoje vis dažniau pradedama taikyti atvejo vadyba, o sveikatos priežiūra tampa vis labiau personalizuota.

Tyrimo tikslas: mokslinès literatūros pagrindu ịvertinti atvejo vadybos taikymo ypatumus klinikinejje praktikoje; pristatyti Klaipėdos universitetinèje ligoninèje taikomą atvejo vadybos modeli.

\section{Darbo objektas ir metodas}

Šio darbo objektas: atvejo vadybos taikymas. Straipsnyje mokslinès literatūros pagrindu aptariamas atvejo vadybos aktualumas teikiant specializuotas sveikatos priežiūros paslaugas onkologiniams ligoniams, pristatomas atvejo vadybos modelis Klaipėdos universitetinèje ligoninèje. Darbe taikyti mokslinès literatūros studijų bei aprašomasis metodai.

Atvejo vadybos turinys. Atvejo vadyba, dar ịvardijama kaip pagalbos koordinavimas, yra kompleksinè intervencija, integruojanti sveikatos priežiūros ir socialinès pagalbos paslaugas asmenims, turintiems ilgalaikių ir sudètingų sveikatos problemų, tokių kaip lètinès ligos [8], todèl laikytinas kaip išskirtinai svarbus elementas ir šių dienų onkologinių ligonių sveikatos priežiūroje. Atvejo vadybos koncepcija gyvuoja jau nuo XX a. pradžios, kilusi pirmiausia psichinès sveikatos, slaugos ir socialinio darbo srityse, todèl pagal savo ištakas glaudžiai siejama su pagalba bendruomenių lygmenyje, ir tik 


\section{6}

nuo $1990 \mathrm{~m}$. atvejo vadyba pradèta integruoti ir ị valstybinių gydymo įstaigų veiklos programas $[10,11]$.

Atvejo vadyboje labai svarbu individualumas versus integruotumas. Pati atvejo vadybos formuluote jau pažymi svarbiausią veiklos principą - individualumą kiekvienam atvejui. Pastebètina, kad $i$ asmenį orientuota prieiga lètiniu ligų gydyme, kurios kertinè ašis yra atvejo vadyba, yra palankiausiai vertinama ir tarptautiniu lygmeniu pripažinta alternatyva, įtvirtinta ne viename naujausiame PSO dokumente [12-15]. Todèl atvejo vadybos kertinis tikslas, atsižvelgiant $\mathfrak{i}$ individualias paciento ypatybes, gerinti paciento sveikatą ir su sveikata susijusią gyvenimo kokybę. Iš specialistų perspektyvos, atvejo vadybininkas veikia kaip individualiai su pacientu dirbantis informacijos brokeris ir pagalbos koordinatorius. Padeda pacientui pasiruošti sprendimus priimti skirtinguose ligos gydymo etapuose bei prisideda prie veiksmingesnio ir efektyvesnio procesu igyvendinimo [16].

Kita vertus, atvejo vadybininko veikloje labai svarbi integralumo sąvoka. Kaip pažymi Amerikos atvejo vadybos asociacija (American Case Management Assocciation), atvejo vadyba - bendradarbiavimo pagrindu sukurtas modelis praktikoje, kuriame įtraukiami skirtingi su ligoniu dirbantys subjektai: slaugytojai, gydytojai, bendruomené, pacientas, socialinis darbuotojas ir kt. specialistai [17]. Todèl šis darbas reikalauja tarpdiscipliniškumo, intensyvaus bendradarbiavimo tarp skirtingų sričių specialistų, kadangi veikiama tarp skirtingų paslaugų sektorių, disponuojama ivvairiais ištekliais [8].

Atvejo vadybos tikslai. Ivvairūs mokslininkai diskutuoja, kokios funkcijos ir tikslai priskirtini atvejo vadyboje. Pastebėtina, kad funkcijų ivvairovè labai priklauso nuo esamo konteksto, organizacijos aplinkos bei pačių pacientų. Tačiau, nepriklausomai nuo šių aplinkybių, iš esmès baziniai atvejo vadybininko tikslai lieka tie patys. Tai yra:

- Planuoti tokias įrodymais pagrịstas veiklas, kurios būtų ekonomiškos ir užtikrintų tikslingą tęstinę pagalbą onkologiniam ligoniui jo gydymosi laikotarpiu.

- Sudaryti ir koordinuoti toki pagalbos planą pacientui, kurio dèka būtų išvengiama neefektyvių, gydymo procesui naudos nesuteikiančių intervencijų, kurios švaisto turimus resursus.

- Suteikti paslaugas ir pagalbą, kuri būtų nukreipta ị neatidèliotinai svarbius nepatenkintus kompleksinius ligonio poreikius.

- Reikšmingai prisidèti ir palaikyti tokią organizacinę aplinką, kuri skatintų mokslinius tyrimus, pažangą paslaugų

1 lentelè. Personalizuotos prieigos (atvejo vadybos) teikiami privalumai.

\begin{tabular}{|c|c|}
\hline Pacientui & Gydančiam personalui \\
\hline $\begin{array}{l}\text { - Aktyvus paciento dalyvavimas savo gydyme, jo ịgalinimas; } \\
\text { - Padidejęs informuotumas apie ligą, pagalbos galimybės įs- } \\
\text { taigoje ir už jos ribų; } \\
\text { - Išaugęs dėmesingumas savo kasdieninės elgsenos ịpročiams; } \\
\text { - Pagerèję ligos valdymo igūdžiai, gebejjimas atpažinti pirmi- } \\
\text { nius pavojaus sveikatai signalus; } \\
\text { - Išaugęs pasitikejjimas savimi, sumažejęs nerimas, distresas; } \\
\text { - Greitesnè socialinė adaptacija; } \\
\text { - Sumažèjusi didelių krizinių situacijų, depresijos išsivystymo } \\
\text { tikimybė; } \\
\text { - Reikšmingai pagerèjusi gyvenimo kokybė; } \\
\text { - Sveikatai palankios elgsenos ugdymas. }\end{array}$ & $\begin{array}{l}\text { - Mažesnis gydymo atsisakymo atvejų skaičius; } \\
\text { - Geresni ligonio gydymosi rezultatai; } \\
\text { - Sumažėjęs netinkamai naudojamų medikamentų atvejų skaičius; } \\
\text { - Sėkminga ir konstruktyvi komunikacija su pacientu; } \\
\text { - Produktyvesnis darbo laikas; } \\
\text { - Produktyvesnės, didesnị pasitenkinimą keliančios konsultacijos } \\
\text { su ligoniu; } \\
\text { - Plètojama specialistų glaudaus bendradarbiavimo kultūra, opti- } \\
\text { maliau paskirstomas darbas kiekvienam specialistui pagal jo kom- } \\
\text { petencijas; } \\
\text { - Nauji igūdžiai, padidèjusi kompetencija; } \\
\text { - Padidejjusi paslaugų kokybė; } \\
\text { - Tobulejjimo galimybės. }\end{array}$ \\
\hline \multicolumn{2}{|c|}{ Organizacijai } \\
\hline \multicolumn{2}{|c|}{$\begin{array}{l}\text { - Patekimo pas specialistą eilių valdymo optimizavimas; } \\
\text { - Užtikrintas priežiūros nuoseklumas ir tęstinumas; } \\
\text { - Sudarytos sąlygos profesionaliai ir savalaikei pagalbai teikti; } \\
\text { - Išaugusi investuojamų i paslaugas pinigų vertė, kadangi teikiamos gydymo paslaugos atliepia individualius poreikius, taip page- } \\
\text { rindamos sveikatos priežiūros baigtis; } \\
\text { - Efektyvus ribotų organizacijos išteklių panaudojimas, lėšų taupymo galimybė; } \\
\text { - Išaugusi pridėtinè paslaugų vertė; } \\
\text { - Sumažejęs sudètingų hospitalizacijos, greitosios pagalbos iškvietimų atvejų skaičius; } \\
\text { - Pagerèjusi paslaugų kokybė, didesnis pacientų pasitenkinimas; } \\
\text { - Išaugęs paslaugų efektyvumas; } \\
\text { - Pagerejęs organizacijos įvaizdis visuomenėje. }\end{array}$} \\
\hline
\end{tabular}


kokybės ir veiklos efektyvumo srityse $[19,20]$.

Vertètų išskirti, kad onkologijoje taikoma atvejo vadyba kaip ligonio sveikatos priežiūros optimizavimo ịrankis ir $i$ asmeni orientuotos pagalbos sąlyga, remiasi 4 baziniais filosofiniais pagrindais: advokacija (1); komunikacija (2); išteklių valdymu (3); edukacine veikla (4)[21]. Apskritai atvejo vadybos mokslininkai ir šios srities praktikai išskiria gausą veiklų, kurios priskirtinos atvejo vadyboje, kaip svarbiausios iš jų minètinos:

pirminio kontakto su pacientu užmezgimas ir palaikymas; paciento poreikių vertinimas ir pagalbos plano sudarymas; sudaryto plano igyvendinimo organizavimas ir procesu koordinavimas; pagalba orientuojantis sistemoje; procesu stebèsena; paciento konsultavimas, švietimas ir informacijos suteikimas; krizių intervencija; paciento ịgalinimas ir jo interesų atstovavimas; suteiktos pagalbos efektyvumo vertinimas ir kt. [8, 9, 19, 22].

Atvejo vadybos taikymo klinikinėje praktikoje naudingumas. Sveikatos priežiūros koordinatorių, atvejo vadybininkų buvimas laikomas kaip vertingiausias ịrankis sprendžiant ịvairaus pobūdžio su pacientų gydymu susijusias problemas, kurios daro reikšmingą poveikị tiek mikro, tiek mezo lygmenimis. Jau ne kartą minèta, kad norint teikti kokybiškas onkologinių ligonių sveikatos priežiūros paslaugas, būtina sukurti tokiems pokyčiams palankią insfrastruktūrą ir orientuotis ị tokias permainas, kurios pagristos naujausiais moksliniais tyrimais ir pasaulinėmis sveikatos priežiūros kryptimis. Kokybė onkologijoje gali būti užtikrinama tik integralioje socialinių ir sveikatos priežiūros paslaugų terpeje, kuri negalima be atvejo vadybos taikymo elementų.

Tačiau būtų neteisinga teigti, kad atvejo vadybininko poreikị lydi tik bendras paslaugų kokybès ir jų teigiamo ivvaizdžio siekis. Iš tiesų kompleksinių paslaugų individualaus koordinavimo ir procesų valdymo diegimas praktinejje veikloje siejamas su gausybe teigiamų pokyčiu tiek patiems pacientams, tiek su juo dirbantiems specialistams ir paslaugas teikiančiai ịstaigai. Mokslinès literatūros analizès pagrindu apibendrinti duomenys pateikiami lentelèje $[12,16,18,20$, 23-25] (1 lentelè).

Kaip galima pastebėti aukščiau pateiktoje lenteleje, atvejo vadybos intervencijos reikšmingai prisideda prie paciento gyvenimo kokybės gerinimo. Turint asmenini atvejo vadybininką, pacientui sumažèja stresas, nerimas ir baimé dèl gydymo, padidejja žinojimas apie savo ligą, ịvairių intervencinių veiklų dèka stiprinami asmens vidiniai resursai, gerinami ligos valdymo ịgūdžiai ir pan.

Vertinant iš su onkologiniu ligoniu dirbančio specialisto perspektyvos, atvejo vadybininko darbas nuima perteklini krūvị nuo onkologų, užtrikrina produktyvesnes konsultacijas, sklandesni gydymo procesą ir specialisto pasitenkinimą darbu. Pavyzdžiui, fragmentuotos ir nekoordinuotos sistemos praktikoje neretai susiklosto situacija, kai gydytojai turi ne tik per labai trumpą konsultacijos laiką plètoti specifini pokalbị dèl gydymo, tačiau jiems taip pat reikia atlikti daug su jų tiesioginiu darbu nesusijusių užduočių, tokių kaip tyrimų registravimas ir pan. Pabrěžtina, kad konsultuojant pacientus susiduriama ir su jų psichosocialinès savijautos keliamomis problemomis, neretai tenka ir nuraminti pacientą, bandyti išsiaiškinti jam kylančias problemas. Todèl atvejo vadybos integravimas nukreiptas būtent spręsti šias problemas. Tyrimai rodo, kad, pavyzdžiui, individualios atvejo vadybininko intervencijos nukreipimas reikiamai pagalbai reikiamu laiku sumažina pacientų gydymo rekomendacijų nesilaikymo ir pasyvaus dalyvavimo savo sveikatos priežiūroje atvejus, gerina paciento ir gydytojo komunikaciją, sprendžia paciento „pasimetimo“ sistemoje problemas [25]. Tai taip pat padidina paciento ir gydytojo pasitenkinimą paslaugomis, pagerina gydymo rezultatus, sumažina išvengiamus prièmimo ị ligoninę atvejus ir gulèjimo joje trukmę [26], todèl integruotoje onkologinio ligonio sveikatos priežiūroje priežiūros koordinavimo elementas yra itin reikšmingas [27, 28].

Galiausiai, labai svarbu iqvertinti ir atvejo vadybininko veiklos poveiki organizaciniams procesams. Pagrindiniai privalumai ir teikiama nauda pateikiama aukščiau esančioje lentelëje (1 lentelè), bet visgi išskirtinio dèmesio reikalauja viena iš aktualiausių ir jautriausių sričių - tai patekimo pas gydytoją specialistą eilių valdymas. Tiek Lietuvoje, tiek tarptautineje praktikoje siekiama ịgyvendinti užsibrežtus standartus, tačiau tai išties sudètinga ir, kaip rodo moksliniai tyrimai, eilių valdymas dažnai sudètingas dèl padrikos sistemos. Tuo tarpu atvejo vadyba su individualiomis intervencijomis gali prisidèti prie sėkmingo šios problemos sprendimo, kadangi kiekvieno paciento koordinavimas ir individualaus atvejo įvertinimas užtikrina, jog bus imtasi visų reikiamų priemonių, kad pacientas kuo greičiau patektų pas gydytojus, reikiamu laiku būtų atlikęs būtinus tyrimus ir pasiruošęs produktyvioms konsultacijoms ar multidalykinès komandos aptarimams [23, 29-31, 24]. Todèl tai gali būti laikoma ne vienintelè, tačiau viena iš svarbiausių atvejo vadybininko teikiamų naudų organizacijai.

Apibendrinat galima pastebeti, kad iš tiesų onkologinio ligonio sveikatos priežiūra prasideda nuo pirmojo paciento kontakto su ji gydančiu personalu, todèl jautrus pokalbis ir sèkminga komunikacija yra būtini užtikrinant pasitikèjimą tarp sergančiojo ir su juo dirbančių specialistų komandos. Be pasitikejjimu grịstos sistemos, kurioje paciento individualūs ir kompleksiniai interesai yra viso gydymo ašis, gydymas net pačiomis pažangiausiomis technologijomis ir metodais bus mažiau sèkmingas ir efektyvus. Todèl ị asmenị orientuotos pagalbos vadybinių principų diegimas praktikoje iš ties turi 


\section{8}

būti už onkologinių ligonių sveikatos priežiūrą atsakingų asmenų diskusijų objektas.

Atvejo vadybininkas Klaipėdos universitetinėje ligoninejje. Siekiant optimizuoti onkologinių ligonių sveikatos priežiūros procesus, efektyviai ir tikslingai panaudoti turimus resursus ir infrastruktūrą teikiant kompleksinès pagalbos ir gydymo paslaugas onkologiniams ligoniams, Klaipèdos universitetinèje ligoninèje bus pradèta taikyti atvejo vadyba.

Atvejo vadybininkas ligoninèje dirbs su pacientais, kurie pas gydytojus specialistus patenka per vadinamaji , $\check{Z} a-$ liaji koridorių“. Pirmiausia ši inovatyvi veikla pradedama kaip pilotinis projektas, kuri igyvendinant bus atliekama eilè mokslinių tyrimų šios intervencijos daromo poveikio veiklos procesams pagristi. Atvejo vadybininko pareigybe bus suteikiama savanorystès pagrindais įstaigoje dirbančiam asmeniui.

Planuojama veiklos apimtis 3-4 nauji atvejai per dieną, nepriklausomai nuo vėžio tipo. Šios iniciatyvos išskirtinumas Lietuvos mastu argumentuojamas taip: vadybininkas nebus tik formalių veiklos procedūrų vykdytojas (užregistravimas tyrimams, apsilankymams pas gydytoją onkologą ir pan.), tačiau bus atsakingas už kompleksinès pagalbos, ịskaitant ir psichosocialinę, valdymą (1 paveikslas).

Kaip matyti iš pateikto paveikslo, Klaipedos universitetinèje ligoninejje dirbančio atvejo vadybininko paskirtis bus užtikrinti tęstinę ir integruotą sveikatos priežiūrą, veikiant gydymo, emocinès, psichologinès, socialinès ir dvasinès pagalbos paslaugų srityse. Vadybininko intervencijos bus vykdomos 3 pagrindiniuose etapuose, kurie yra:

1. Pacientų atrankos etapas. Šiame etape atvejo vadybininko pagrindiné funkcija yra artimiausių laisvų vizitų sutikrinimas pirmam susitikimui su gydančiu gydytoju, individualiai ịvertinant situacijos sudètingumą ir skubumą.

2. Pagalbos planavimo, organizavimo ir koordinavimo etapas. Tai didelès apimties, tęstinumo ir integruotumo reikalaujantis etapas, kuriame su kiekvienu pacientu bus dirbama individualiai nuo pirmo apsilankymo pas gydytoją onkologą, multidalykinès komandos aptarimo, toliau pereinat prie gydymo bei jo eiliškumo paskyrimo ir intervencijas tęsiant iki gydymo pabaigos. Atvejo vadybininkas bus paskirtas kaip pirminis paciento kontaktinis asmuo, kad pacientas dèl neaiškumų, kurie kilo gydymo kurso eigoje, pirmiausia galètų kreiptis i atvejo vadybininką ir suderinti tolesni paciento kelią, priklausomai nuo aplinkybių.

3. Suteiktos pagalbos analizè ir ịvertinimas. Šiame etape ìvairių mokslinių instrumentų pagalba bus vertinami intervencijų efektyvumas, paciento pasitenkinimas suteiktomis paslaugomis, stebimas su onkologiniais ligoniais dirbančiu specialistų veiklos efektyvumo, gydymo procesų sklandumo ir produktyvumo, pačių specialistų profesinès veiklos gero-

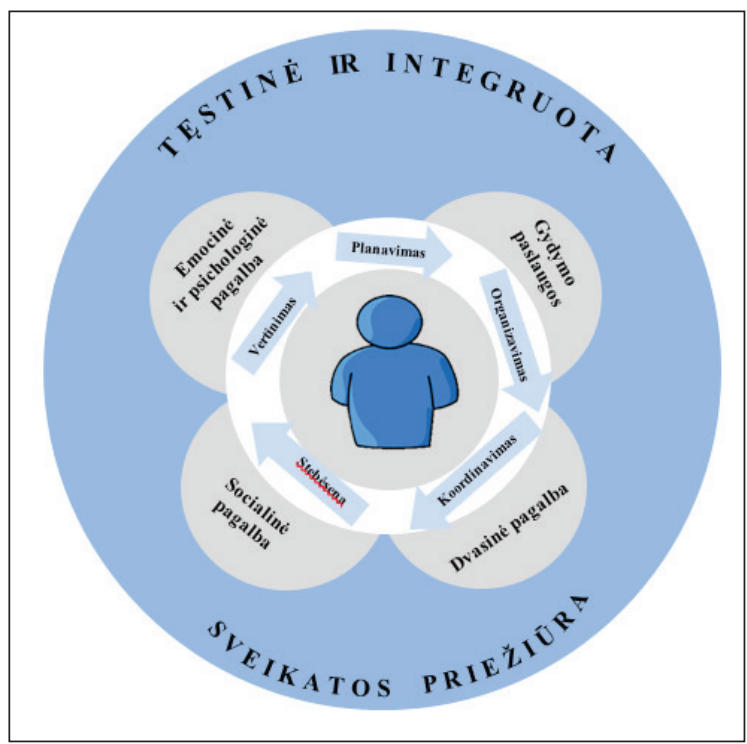

1 paveikslas. I asmenį orientuotos atvejo vadybos modelis Klaipèdos universitetinèje ligoninèje.

vès pokytis.

Taikant atvejo vadybą onkologinių ligonių sveikatos priežiūroje, Lietuvos mastu bus sukurtas naujausias pasaulines tendencijas atitinkantis modelis, kuriuo siekiama:

- Efektyviai paskirstyti ir išnaudoti ligoninès resursus.

- Sumažinti stacionarinių paslaugų naudojimąsi didinant ambulatorines paslaugas.

- Racionaliai valdyti pacientų srautus.

- Reikšmingai padidinti specialistų ir pacientų pasitenkinimą paslaugomis.

- Vykdyti efektyvesnę onkologinių ligų prevenciją.

- Vykdyti efektyvią savižudybių ir psichikos sveikatos sutrikimų prevenciją.

- Vykdyti Europos ir nacionalines onkologinių ligų sriti reglamentuojančias direktyvas.

\section{Išvados}

Kuriant integruotą ir ị asmenị orientuotą, dar kitaip personalizuotą onkologinių ligonių sveikatos priežiūrą labai svarbu į gydymo įstaigos veiklos procesus įtraukti atvejo vadybą. Pati atvejo vadyba nèra galutinai apibrež̌ta, jai būdingos ịvairios variacijos priklausomai nuo konteksto, kuriame ši inovacija diegiama. Tačiau, kuriant geraja praktika paremtus modelius, labai svarbu išsaugoti esminius atvejo vadybos elementus. Teigtina, kad atvejo vadybininko intervencija onkologijoje palaiko koordinavimą, sveikatos priežiūros ir socialinių paslaugų integraciją taip užtikrinant tikslingą kompleksinę pagalbą sergantiesiems. Svarbu suvokti, kad šiuolaikinèje sveikatos priežiūroje dèl moderniujų 
technologijų raidos, mokslinių tyrimų ir ịrodymais pagrịstos medicinos pasiekimų, vis didejjančio paciento ịgalinimo, jo teisių ir gyvenimo kokybès vaidmens išaugimo, gydymo istaigu praktika ir organizaciniai modeliai privalo keistis. Atvejo vadyba yra ịrankis, kuris tinkamai naudojamas būtent ir sudaro sąlygas efektyvių paslaugų ir aukščiausios kokybès užtikrinimui sveikatos priežiūroje.

\section{Literaūra}

1. Chakraborty $\mathrm{S}$, Rahman T. The difficulties in cancer treatment. Ecances Medical Science 2012; 6(16).

2. Mirties priežastys (Išankstiniai duomenys). Vilnius: Higienos Instituto Sveikatos informacijos centras, 2018. http://www. hi.lt/uploads/pdf/leidiniai/Statistikos/Mirties_priezastys/ MPR_2017_isankstiniai.pdf. Accessed November 21, 2018

3. Singlettery J. The cost of cancer. Addressing patient costs. American Cancer Society; 2018. https://www.fightcancer.org/ sites/default/files/Costs $\% 20 \mathrm{of} \% 20$ Cancer\%20-\%20Final $\% 20$ Web.pdf. Accessed November 21, 2018.

4. Hersch F, Martin J. Meeting the health care challenges of the 21 st century. The George Institute for Global Health, Oxford University; 2014. http://sbsplatinum-prod.sbs.ox.ac.uk/sites/ default/files/Skoll_Centre/Docs/essay-hersch.pdf. Accessed November 21, 2018.

5. Brédart A, Beaudeau A, Young T. et al. The European organization for research and treatment of cancer - satisfaction with cancer care questionnaire: revision and extended application development. Psychooncology 2016;26(3):400-404.

https://doi.org/10.1002/pon.4127

6. Abrahamson K, Durham M, Norton K, Doebbeling B, Doebbeling C, Anderson J. Provision of psychosocial care for cancer patients. J Prim Care Community Health 2011; 2(4):220-224. https://doi.org/10.1177/2150131911407201

7. European Guide On Quality Improvement In Comprehensive Cancer Control. Slovenia: Scientific Institute of Public health, Brussels, Belgium; National Institute of Public Health, 2017.

8. Lukersmith S, Millington M, Salvador-Carulla L. What is case management? A scoping and mapping review. Int J Integr Care 2016;16(4):2. doi:10.5334/ijic.2477

https://doi.org/10.5334/ijic.2477

9. Kanter J. Colette: a clinical case management perspective. Clin Soc Work J 2016; 44(4):341-344. https://doi.org/10.1007/s10615-016-0593-2

10. Cesta T. What's old is new again: the history of case management. Reliasmedia.com. https://www.reliasmedia.com/ articles/141367-whats-old-is-new-again-the-history-of-casemanagement. Published 2018. Accessed November 20, 2018.

11. Kersbergen A. Case management: A rich history of coordinating care to control costs. Nurs Outlook 1996;44(4):169-172.

https://doi.org/10.1016/S0029-6554(96)80037-6

12. NHS England Personalised Care \& Support Planning Handbo- ok - Core Information. Person Centred Care/Coalition for Collaborative Care/Medical directorate; 2016. https://www. england.nhs.uk/wp-content/uploads/2016/04/core-info-caresupport-planning-1.pdf. Accessed November 20, 2018.

13. Integrated Care Models: An overview. Pasaulinè Sveikatos Organizacija; 2016. http://www.euro.who.int/en/health-topics/ Health-systems/health-services-delivery/publications/2016/integrated-care-models-an-overview-2016. Accessed November 20, 2018.

14. Framework On Integrated, People-Centred Health Services. Pasaulinè Sveikatos Organizacija; 2016.< http://apps. who.int/ gb/ebwha/pdf_files/WHA69/A69_39-en.pdf?ua=1. Accessed November 20, 2018.

15. WHO Global Strategy On People-Centred And Integrated Health Services. Pasaulinè Sveikatos Organizacija; 2015. http://apps.who.int/iris/bitstream/handle/10665/155002/ WHO_HIS_SDS_2015.6_eng.pdf;jsessionid=E041FE6A10E5 1B841C532FACB264E685? sequence=1. Accessed November 20, 2018.

16. Gilbert J, Green E, Lankshear E, hughes E, Burkoski V, Sawka C. Nurses as patient navigators in cancer diagnosis: review, consultation and model design. Eur J Cancer Care (Engl) 2010;20(2):228-236. doi:10.1111/j.1365-2354.2010.01231.x https://doi.org/10.1111/j.1365-2354.2010.01231.x

17. ACMA : Scope of Services. Acmaweb.org. https://www.acmaweb.org/section.aspx?sID=136\&fbclid=IwAR1S78mQ8vN DJcVMzrpY911BzZ_pcrajr6RIQ2s81Zsed1Qy7EHbRfOIJ8E. Published 2018. Accessed November 20, 2018.

18. Loscalzo M. Handbook of oncology social work: psychosocial care for people with cancer. Edited by Grace Christ, Carolyn Messner, and Lynn Behar. 2015. 872 pages. \$110.00. ISBN: 9780199941926. Psychooncology. 2016;25(3):359-360. doi:10.1002/pon.4101 https://doi.org/10.1002/pon.4101

19. Fabbri E, De Maria M, Bertolaccini L. Case management: an up-to-date review of literature and a proposal of a county utilization. Ann Transl Med 2017;5(20):396-396. doi:10.21037/ atm.2017.07.26

https://doi.org/10.21037/atm.2017.07.26

20. Ramey M, Daniels S. Hospitalists and case managers. Lippincott's Case Management. 2004;9(6):280-286. doi:10.1097/00129234-200411000-00007

https://doi.org/10.1097/00129234-200411000-00007

21. Oncology case management: optimizing care pathways. Oncology Nursing News. https://www.oncnursingnews.com/ publications/oncology-nurse/2018/march-2018/oncology-case-management-optimizing-care-pathways. Published 2018. Accessed November 20, 2018.

22. Standards of practice for case management. Case management society of America; 2016. https://www.miccsi.org/wp-content/ uploads/2017/03/CMSA-Standards-2016.pdf. Accessed November 17, 2018.

23. Suss S, Bhuiyan N, Demirli K, Batist G. Toward imple- 
menting patient flow in a cancer treatment center to reduce patient waiting time and improve efficiency. J Oncol Pract 2017;13(6):e530-e537.

https://doi.org/10.1200/JOP.2016.020008

24. Toustrup K, Lambertsen K, Birke-Sørensen H, Ulhøi B, Sørensen L, Grau C. Reduction in waiting time for diagnosis and treatment of head and neck cancer - a fast track study. Acta Oncol (Madr). 2011;50(5):636-641. doi:10.3109/02841 86x.2010.551139

https://doi.org/10.3109/0284186X.2010.551139

25. Harter TD. Frustrated care: ethics, obligations and strategies in caring for challenging and noncompliant patients. 63rd ed. ACMA; 2018. http://www.acmaweb.org. Accessed November $5,2018$.

26. Curry N, Ham C. Clinical and service integration: the route to improved outcomes. The Kings Fund; 2018. https://www. kingsfund.org.uk/sites/default/files/Clinical-and-service-integration-Natasha-Curry-Chris-Ham-22-November-2010.pdf. Accessed November 20, 2018.

27. Aitken K, von Treuer K. Organisational and leadership competencies for successful service integration. Leadership in Health Services 2014;27(2):150-180. doi:10.1108/lhs-08-2012-0028 https://doi.org/10.1108/LHS-08-2012-0028

28. Fann J, Ell K, Sharpe M. Integrating psychosocial care into cancer services Journal of Clinical Oncology 2012;30(11):11781186 .

https://doi.org/10.1200/JCO.2011.39.7398

29. Sun J, Lin Q, Zhao P. et al. Reducing waiting time and raising outpatient satisfaction in a Chinese public tertiary general hospital-an interrupted time series study. BMC Public Health 2017;17(1).

https://doi.org/10.1186/s12889-017-4667-Z

30. Chen Y, Chang Y, Tsou Y, Chen M, Pai Y. Effectiveness of nurse case management compared with usual care in cancer patients at a single medical center in Taiwan: a quasi-experimental study. BMC Health Serv Res 2013;13(1).

https://doi.org/10.1186/1472-6963-13-202
31. Kallen M, Terrell J, Lewis-Patterson P, Hwang J. Improving wait time for chemotherapy in an outpatient clinic at a comprehensive cancer center. J Oncol Pract 2012;8(1):e1-e7. https://doi.org/10.1200/JOP.2011.000281

\section{THE APPLICATION OF CASE MANAGEMENT IN KLAIPEDA UNIVERSITY HOSPITAL FOR THE DEVELOPMENT OF PERSONALISED CANCER CARE \\ S. Savickaitè, A. Česas}

Key words: case management, personalised (person-centered) cancer care, complex treatment, integrated health care, holistic approach.

\section{Summary}

Cancer health care requires an individual managerial approach regarding the complexity and the high cost of the disease treatment. The application of personalised (person-centered) support is considered to be mostly accepted alternative in order to manage the cancer disease challenges in both most cost-efficient and costeffective ways. Moreover, personalised cancer care is taken as a comprehensive service quality and patient satisfaction assurance at present. It should be emphasized that personalised health care for cancer patients, which is based on a holistic approach, encourages the organizational changes in the service provision. As a consequence, case management is increasingly being introduced in the routine practice of medical institutions.

The aim of the study: on the basis of the scientific literature, to evaluate the peculiarities of case management application in clinical practice and to present the case management model applied at Klaipeda University Hospital.

Correspondence to: samantasavickaite@yahoo.com

Gauta 201811-26 